\title{
START-UP PROCESSES' EFFICIENCY OF TURBINE JET ENGINES
}

\section{EFEKTYWNOŚĆ PROCESÓW ROZRUCHU TURBINOWYCH SILNIKÓW ODRZUTOWYCH}

\author{
Antoni Jankowski ${ }^{1}$, Mirosław Kowalski ${ }^{2}$ \\ ${ }^{1}$ Instytut Techniczny Wojsk Lotniczych \\ ${ }^{2}$ Wyższa Szkoła Oficerska Sił Powietrznych \\ E-mail:antoni.jankowski@itwl.pl; m.kowalski@wsosp.pl
}

\begin{abstract}
The paper presents diagnoses of example start-up processes of drive units built in military aircraft operated in the Dęblin's "School of Eaglets" during the flight. The significance of this process is very important, especially from the point of view of flight safety, especially as it concerns the training aircraft, on which officer cadets-candidates for pilots are trained. The diagnosis of the start-up process was conducted using data from on-board flight recorders recorded during a flight training, whose aim was an emergency launch of particular drive units, and with the help of the so-called phase mapping of the selected operating parameters of the particular flight drive systems. The standard diagram of typical start-up systems was shown, while presenting their base subassemblies. At the end, the obtained results and the main problems that need intervention were commented, as well as further preventive activities were proposed.
\end{abstract}

Keywords: turbine jet engine start-up, starting-up the engine during the flight, diagnosis of aircraft engine start-ups

Streszczenie: Artykut przedstawia diagnozowanie przykładowych procesów rozruchu zespołów napędowych zabudowanych $w$ wojskowych statkach powietrznych podczas lotu, eksploatowanych w Dęblińskiej Szkole „Orlat”. Znaczenie tego procesu jest bardzo ważne, glównie z punktu widzenia bezpieczeństwa lotów, szczególnie, że dotyczy szkolnych statków powietrznych, na których szkoleni sa podchorażzowie - kandydaci na pilotów. Diagnozowanie procesów rozruchu przeprowadzono z wykorzystaniem danych $z$ pokladowych rejestratorów lotu zapisanych podczas szkolenia lotniczego, którego celem było awaryjne uruchomienie poszczególnych zespolów napędowych oraz za pomoca tzw. odwzorowania fazowego wybranych parametrów pracy poszczególnych, lotniczych zespołów napędowych. Przedstawiono standardowy schemat typowych ukladów rozruchowych, prezentując przy tym zasadnicze ich podzespoły. Na zakończenie skomentowano uzyskane wyniki oraz główne problemy wymagające interwencji, a także zaproponowano propozycje dalszych dziatań profilaktycznych.

Stowa kluczowe: rozruch turbinowego silnika odrzutowego, uruchomienie silnika podczas lotu, diagnozowanie rozruchów silników lotniczych 
Start-up processes' efficiency of turbine jet engines

Efektywność procesów rozruchu turbinowych silników odrzutowych

\section{Introduction}

The start-up process of drive units during the flight of training aircraft, which are equipped by the Dęblin's "School of Eaglets" and intended for flight training of future pilots, is a very important element in terms of flight safety.

During use of the engine in the air, there is a possibility of its spontaneous turn-off. The causes of the turn-off, assuming that the fuel system operates correctly, are numerous, e.g.: execution of rapid manoeuvres at an earlier reduction in engine speed. This can be caused by an asymmetric airflow around the engine intake, incorrect regulation of inlet diffusers, flow disturbances caused by e.g. firing of rockets, icing of the inlet, etc.

The construction of the aircraft engine start-up system is often an indicator of ranges of the aircraft's possible applications. The start-up system - regardless of the type - consists of three main systems: start-up automatics (exercising also a control function), a basic generator, and a power source (0). The power source can be an integral part of the aircraft or engine (the so-called dual generator).

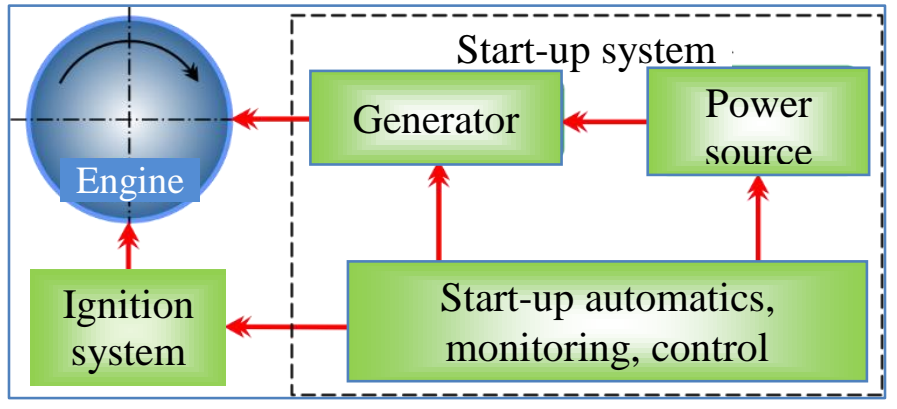

Fig. 1. Diagram of the start-up system [3]

In modern turbine jet engines, start-up is automatic in accordance with the specially tailored programme of the generator turn-on/turn-off, ignition and start fuel. The type of start-up system determines also its weight and dimensions, which is important especially in relation to small aircraft, as well as the necessary actions to be performed by the pilot during its launch. This is especially important during the flight training in the air of the future pilots and it is directly related to flights' safety [7].

The task of the start-up system of the areo engine is to give the necessary rotational speed of the engine power transmission (an air compressor and turbine unit), at which the power developed by the turbine $N_{t}$ is greater than the sum of the power pulled by the air compressor $N_{s}$ and other engine subassemblies - in accordance with the balance of the power of the turbine specified by the dependency:

$$
N_{t} \geq N_{S}+N_{a g r},
$$

where: $\boldsymbol{N}_{\boldsymbol{a g r}}$ - the power needed for the units' drive and overcoming the frictional resistances. 
The engine start-up is an unsteady process lasting from the standstill to the achievement of the necessary, minimum rotational speed under ground conditions, and - during the flight - also from the minimum speed of "autorotation" to the minimum rotational speed (often referred to as minimum flying speed). The engine start-up in the range to the minimum rotational speed must be carried out continuously with the specified acceleration.

The research and analysis of the start-up processes were conducted on, among other, the PT6A-25C engine by Pratt \& Whitney constituting a drive unit of the PZL-130TC-II "Olik" aircraft, on the PZL-10WM engine constituting the drive unit of the W-3 "Sokól" helicopter, as well as the SO-3 turbojet engine of the TS-11 "Iskra" aircraft. These are the basic aircraft equipped by the Dęblin's School of Eaglets, whose task is to secure the practical flight training in the air [1,2]. The data for the analysis were derived from on-board flight data recorders type S23-a by the Air Force Institute of Technology, which are built in the above-mentioned aircraft. The analysis was conducted mainly using the so-called phase diagrams of the selected engine operation parameters, described with the general dependency:

$$
\frac{d X}{d t}=f(X)
$$

where:

$X$ - analysed parameter,

$t$ - time [s].

Moreover, it was noted that the rate of acceleration of the engine has a decisive influence on the obtained start-up time, which is one of the main parameters of all start-up systems. It was indicated that securing the so-call surplus power, which requires a continuous supply of fuel and air into the combustion chamber of the engine, is necessary to maintain acceleration at the required level. The selected characteristics obtained during the start-up processes analysis of particular drive units during flight were presented.

\section{Procedures of aircraft engine start-ups}

The start-up of the turbo-prop engine is slightly different than the one of the jet engine. This is because the specified rotational speed of the air compressor turbine is called mainly by the autorotation of a propeller set at appropriate angles of attack. Depending on the angle of the propeller blades setting, there are several opportunities of cooperation of the propeller with the engine. The most favourable setting is the one, in which the blades are set in the so-called "pennant" (the angle of attack of the propeller in relation to the plane of rotation is near $90^{\circ}$ ), which gives a minimum drag. 
Start-up processes' efficiency of turbine jet engines

Efektywność procesów rozruchu turbinowych silników odrzutowych

The surplus power of the turbine from the dynamic pressure is consumed on the internal air stream damping in the engine.

For the drive unit of the PZL-130TC-II „Orlik” aircraft (the PT-6A engine), there is no automatic ability to set the propeller in the "pennant" setting.

The pilot is required to switch the power lever manually (fig. 2) to the engine rotational speed range of the idle run in order to attack the microswitch responsible for moving the propeller blades in the "pennant" position. This solution is not so fortunate from the point of view of the need for the proper response of the crew in a very stressful situation, which often takes place during the spontaneous turn-off of the engine, especially in relation to the beginner pilots.

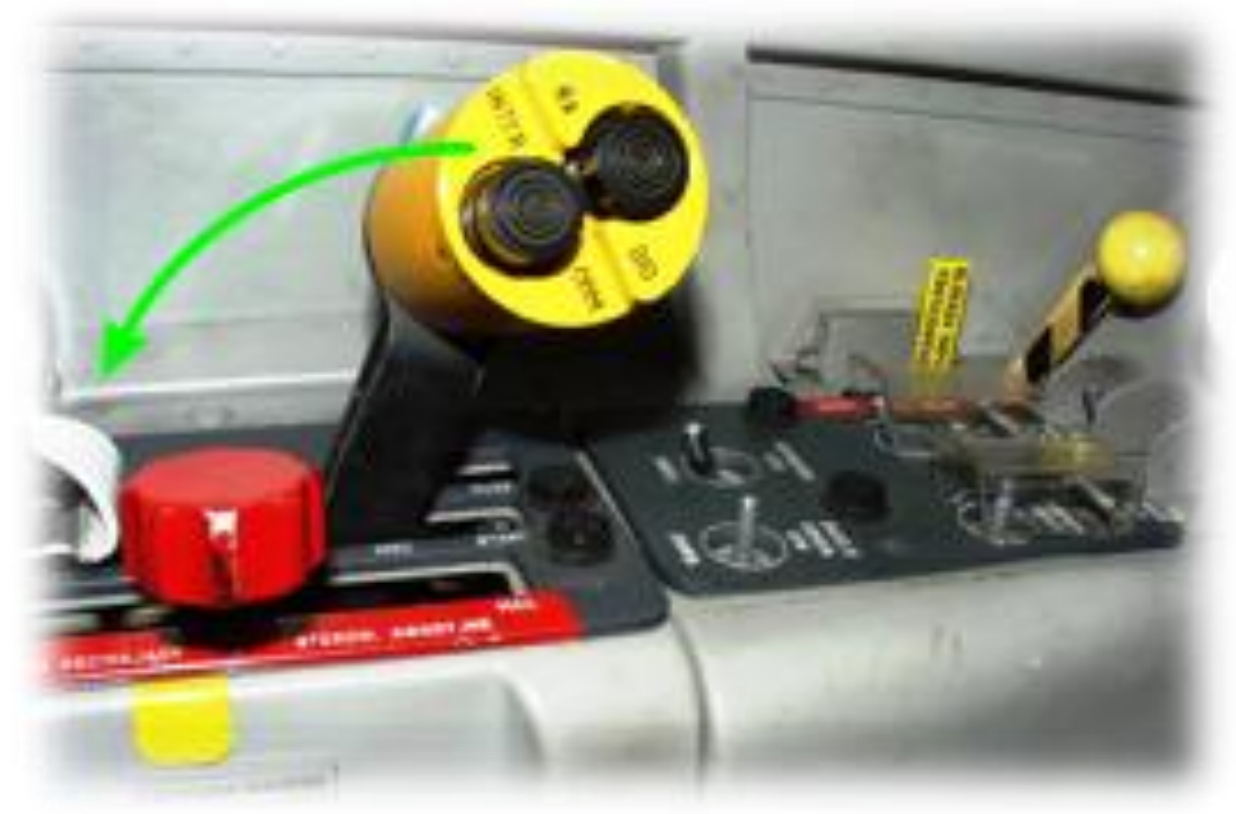

Fig.2. View of the power lever (a green arrow - direction of lever movement)

During the qualification tests, three subsequent start-ups were conducted in the air at an altitude of about $3000 \mathrm{~m}$ and velocity in the range from 230 to $260 \mathrm{~km} / \mathrm{h}$. The first one was executed after 30 seconds after turning off the engine; the second one, when the rotational speed of the engine dropped below 50\%, and the third one also after 30 seconds after the emergency turn-off $[4,5]$.

\section{Results of aircraft engine start-ups during the flight}

The visualisation of particular start-ups of this engine is shown in fig. 3, which presents the course of engine rotational speed in function of the flight duration.

During start-up of the engine in the air, the propeller - in a certain range of angles of attack - is an additional source of significant torque, exceeding manifold the maximum torque of the generator. Thus, the time required to achieve the rotational 
speed of the idle run (released gas) by the engine is slightly shorter than the startups time on the ground. The time histories of the change in engine rotational speed during execution of the analysed starts-up show their slight reduction, apart from emergency launch.

The conducted analysis of change in the drive unit basic operation parameters during subsequent start-ups allows to determine which start-up method is the most effective and proceeds the most gently.

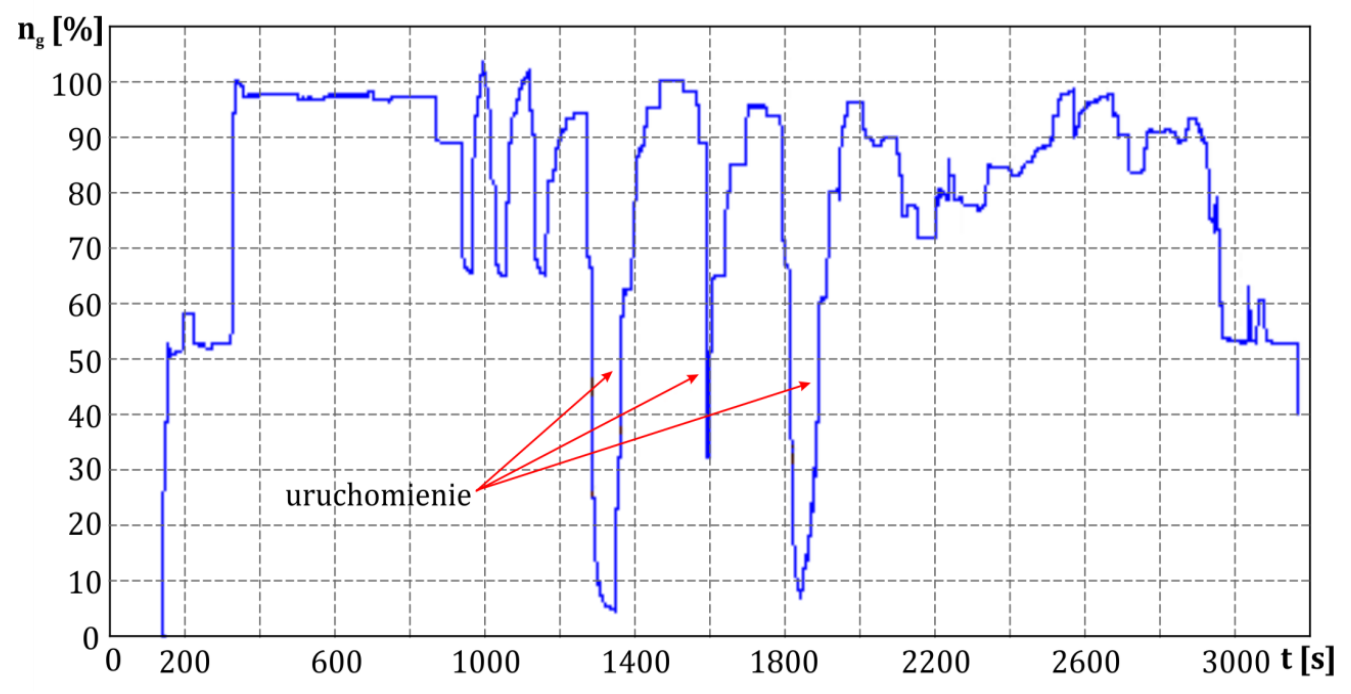

Fig. 3. The course of change in the engine rotational speed during the flight to check the possibility of starting up the engine in the air

Legend: uruchomenie - launch

The applied procedure of the start-up of the PZL-10WM engine, built in the W-3A "Sokót" Polish helicopter, is another example indicating on an inconvenience in the startup procedure of the aircraft drive unit. The PZL-10WM type turbine engine is built in this helicopter. It is equipped with a full authority digital engine control (FADEC).

Within the in-flight tests, the so-called cold and hot start-ups were conducted at altitudes up to $4,000 \mathrm{~m}$. In one case, at altitudes above 3,000 meters (i.e. 3,500 and 4,000 m), attempts to perform start-ups failed. The reason for this state of affairs was not launching an additional bleed air (e.g. for the needs of an airframe - prescribed in the User Manual of this engine).

The fig. 4 presents the one of the unsuccessful attempts to start-up the left engine in flight at an altitude $H \approx 3,500 \mathrm{~m}$, at flight velocity $V_{p} \approx 115 \mathrm{~km} / \mathrm{h}$. The visible phase mapping is typical for the very generator's operation, which suggests that the increase in the rotational speed $n_{l}$ to almost $30 \%$ were just the consequence of the generator operation [6]. 
Start-up processes' efficiency of turbine jet engines Efektywność procesów rozruchu turbinowych silników odrzutowych

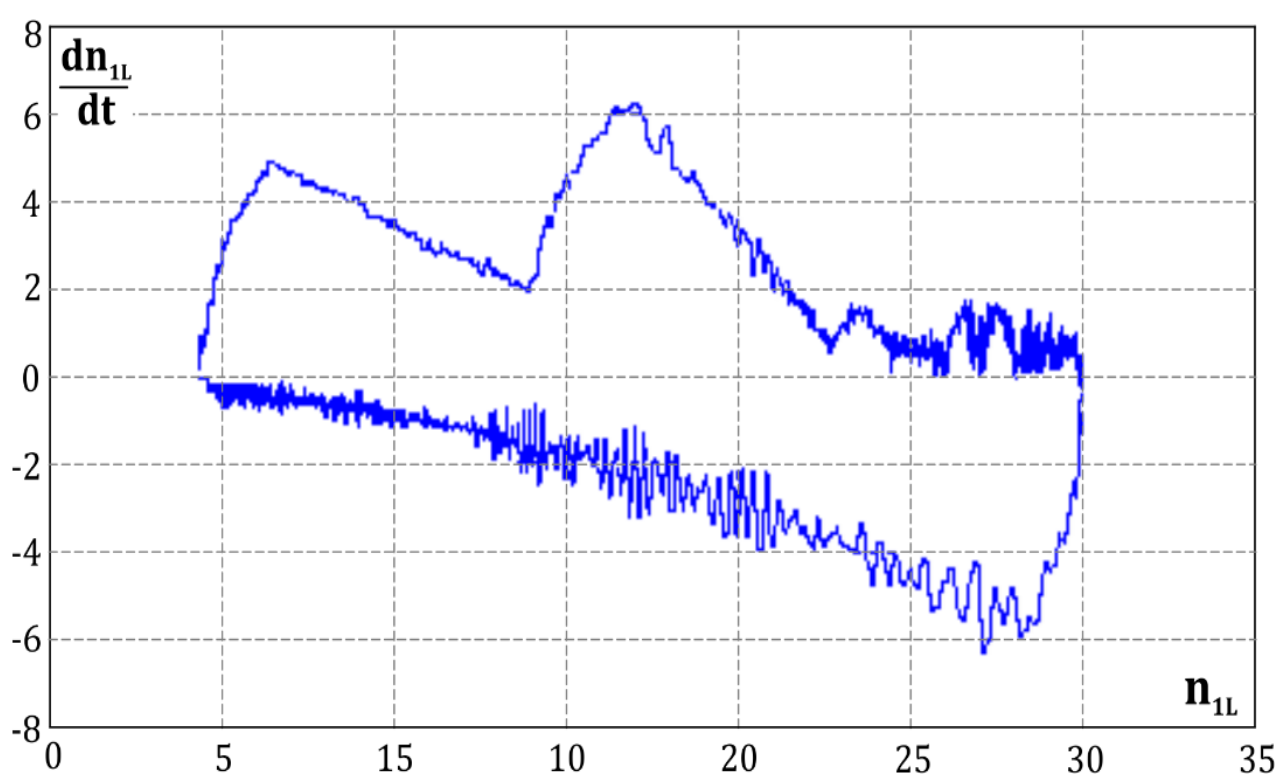

Fig. 4. The phase mapping of growth of the rotational speed of the engine $n_{I L}$ during the failed start-up in flight.

Looking at the course presented in fig. 5 depicting the flow rate of fuel supplied to the combustion chamber in the function of the rotational speed $n_{l}$ of a turbocharger, one can state that at proper air pressure $\mathrm{p}_{2}$ behind the engine compressor, the start-up would have ended with a positive result.

In subsequent checks, after taking into account the need of the additional bleed air from the compressor, the attempts were already positive, and their parameters were consistent with the technical conditions (TC). It should be noted, however, that the ensuing instance of failed start-up of the engine at high altitudes, in the presence of subzero ambient temperatures, without the use of the additional bleed air is a big problem worth of deeper analysis. Since it requires the crew's remembering about additional activities in a very stressful situation (an emergency situation) and at occurring very often deficit of time. For this reason, the application for consideration of possibility of the programme consideration of such a situation directly in an electronic box - of course, in the phase of further development and modernisation of the full authority digital engine control - was sent to the Producer of the helicopter.

The next example of very complex procedure of start-up (during the flight) concerns a single flow, turbine jet engine SO-3 built in the TS-11 "Iskra" aeroplane. This aeroplane is quite simple to use - it is designed for an advanced training of young pilots at the Polish Air Force Academy in Dęblin - Poland. In the ordered procedure of the engine start-up during the flight, there are many activities to accomplish, which, in addition, must be carried out in a correct order. 


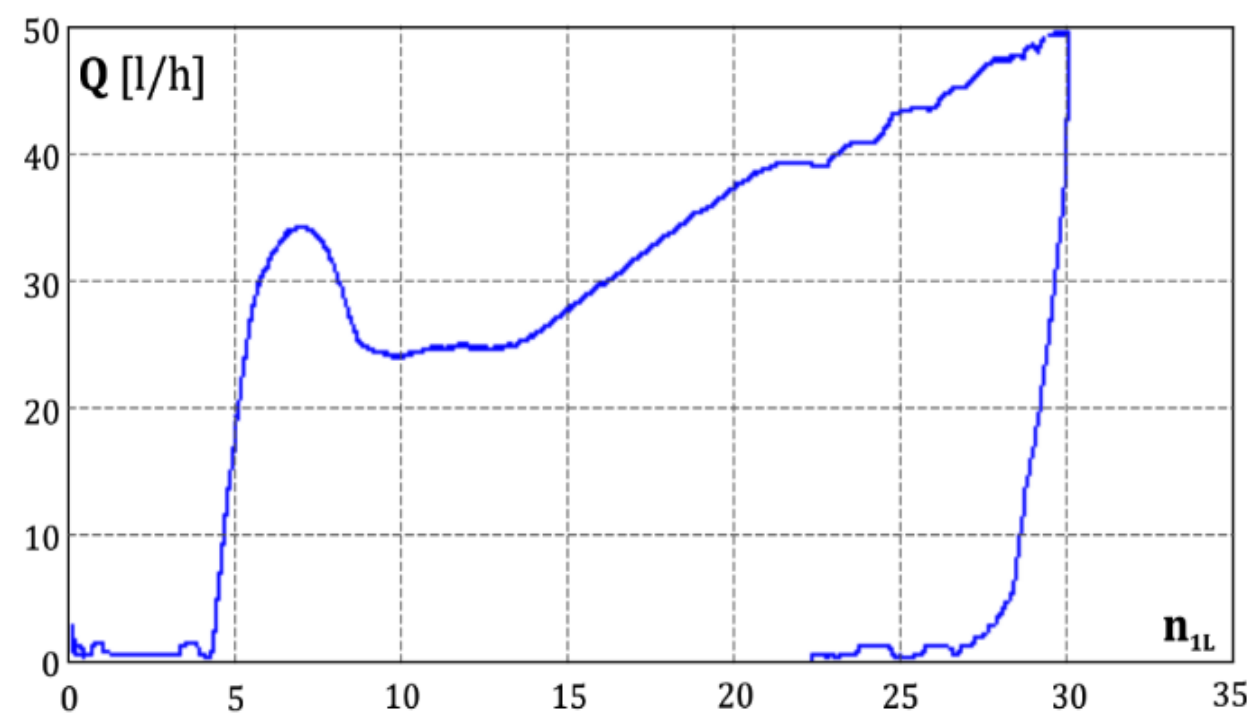

Fig. 5. Fuel flow rate $Q$ in the function of the turbocharger rotational speed NI during the failed attempt of the left engine start-up in flight.

Moreover, there is a need for continuous monitoring the temperature growth of the exhaust gases in order not to exceed the maximum permissible value, i.e. $800^{\circ} \mathrm{C}$. This is very important because its excess forces the pilot to stop the engine start-up. The re-attempt to launch the engine, after such an interruption, requires the socalled engine purging for 20 seconds in order to remove surplus amount of fuel, which - in extreme cases - may lead to a fire. This is very dangerous because of the fairly frequent lack of time for the execution of all these activities and it requires the implementation of automated start-up systems.

However, it must be noted that very often, after unsuccessful attempts to launch the engine, it is necessary to analyse the causes of this incident. This will allow for the development of appropriate prevention and avoiding such events in the next training flights. For this type of analysis, among others, the already mentioned method of phase mapping of rotational speed growth can be applied. It allows, among others, to recognise irregularities in the engines control through a comprehensive analysis of the operation (or the technical state) of all elements of the engine start-up system. The increase in engine rotational speed during start-up in the function of time provides (sometimes) pretty poorly noticeable symptoms its disturbance (a circle line in fig. 6).

As late as presenting the so-called phase diagram of rotational speed growth, it can be quite explicitly observed that this small disturbance of the rotational speed growth is the result of, for example, growth of an exhaust gas limiter system, which slows its growth with pretty rapid reduction in the amount of fuel supplied to the combustion chamber. 
Start-up processes' efficiency of turbine jet engines Efektywność procesów rozruchu turbinowych silników odrzutowych

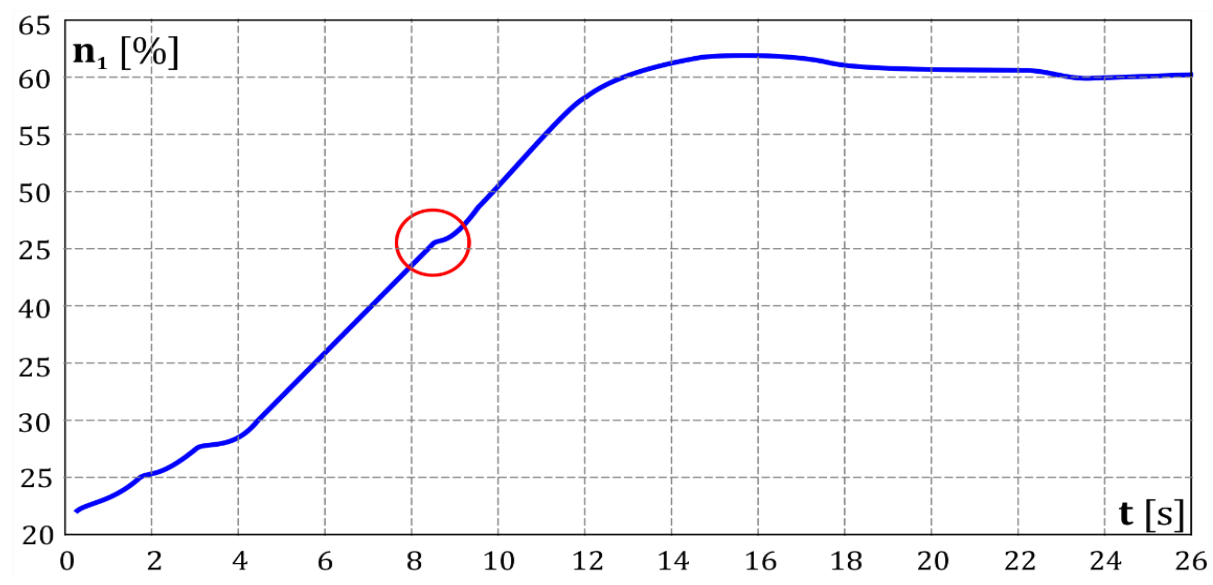

Fig. 5. Change in the engine rotational speed during start-up of the SO-3 engine during flight

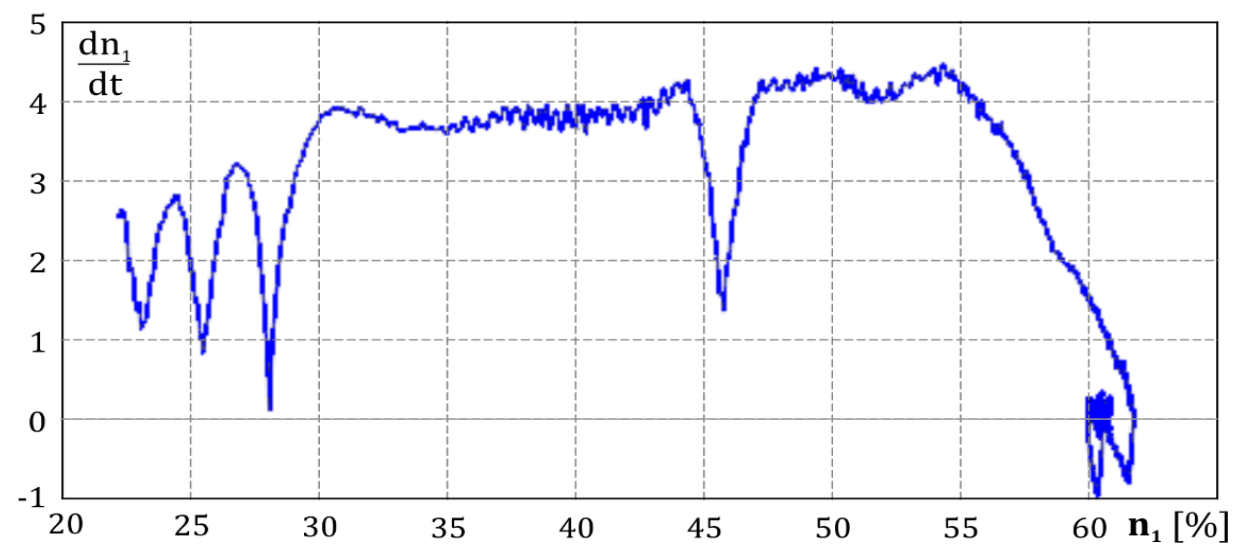

Fig. 6. Phase mapping of growth of the rotational speed during the start-up in flight

Such a phenomenon is illustrated in fig. 7, where because of a relatively rapid gradient of the increase in rotational speed (as a result of supplying excessive amounts of fuel into the combustion chamber) at a relative rotational speed of about $45 \%$, a significant reduction of supplied fuel amount occurred, which caused a decrease in the rotational speed, and, thus, the decrease in the gradient of the exhaust gas temperature occurred. This state of affairs greatly strains - especially rotating engine components (such as e.g. compressor and turbine blades) - due to excessive thermal loads occurring simultaneously.

Such an analysis allows for earlier response and readjustment of the engine start-up system, which may significantly reduce negative phenomena accelerating the destruction processes of sensitive parts of the aero engine. 


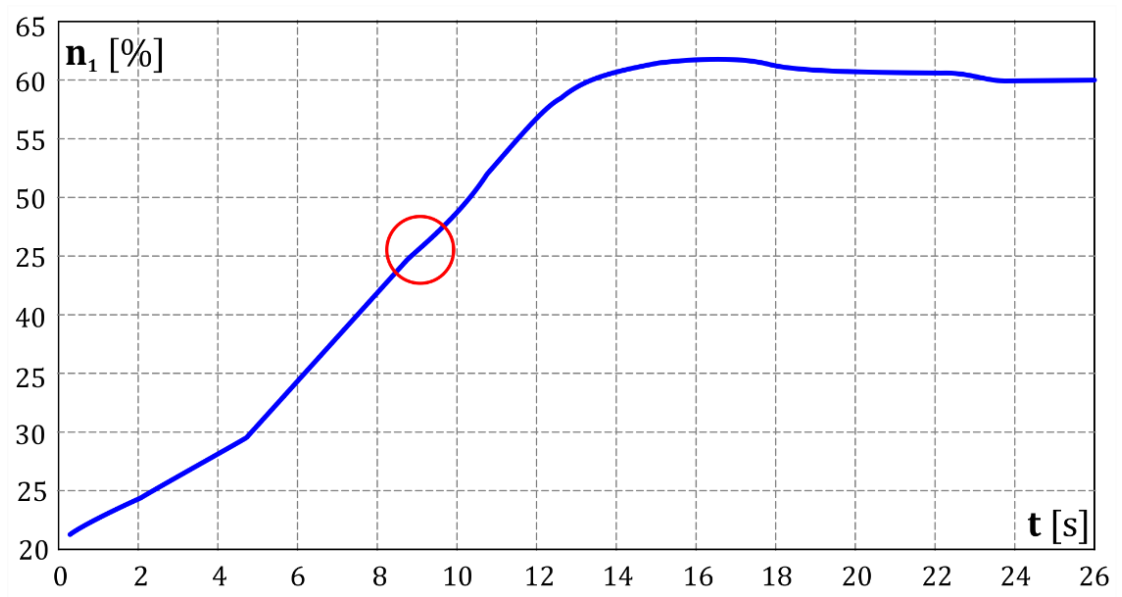

Fig. 7. Change in the rotational speed of the engine during start-up of the SO-3 type engine during the flight (much less collapse of rotational speed growth visible)

Figs. 8 and 9 present similar characteristics, but after the executed engine control, which significantly reduced the growth dynamics in engine rotational speed $n_{1}$ during start-up, and, thus, the temperature gradient of exhaust gases, which caused excessive burdening the engine elements, especially the rotating ones. This is mostly result of the fact that the exhaust gases of very high temperature work on very much cooled blades. This significantly weakens the fatigue strength of these elements and may lead to their coming off (damage).

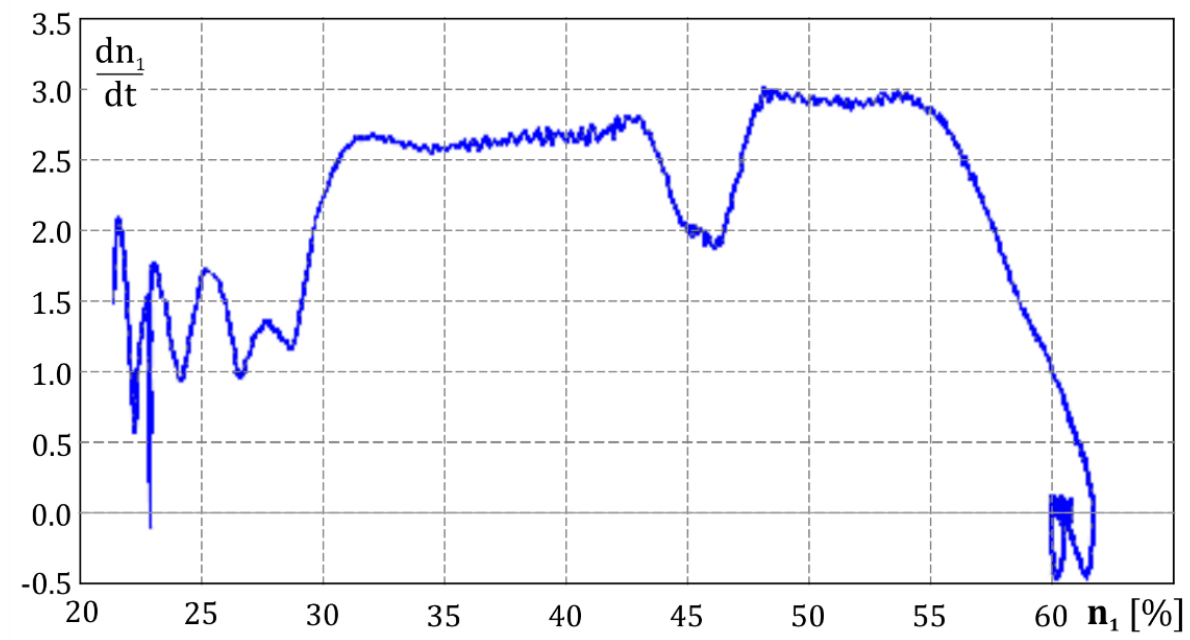

Fig. 8. Phase mapping of growth of the rotational speed during the start-up in flight (much lower slowing of the rotational speed visible) 
Start-up processes' efficiency of turbine jet engines

Efektywność procesów rozruchu turbinowych silników odrzutowych

\section{Conclusion}

The executed analyses of the drive units' start-up processes analysis show that the start-up systems of the drive units are effective and provide good operational (practically) in all conditions. However, they are not devoid of minor flaws, whose existence directly affects the safety of flights and requires taking preventive actions or even modernisation of certain elements of the given start-up system.

Particular attention was paid to cases of failed engine start-ups during the flight, which were affected by mainly additional activities, without which it is impossible to launch the engine during the flight, imposed on the pilot. This is very important from the point of view of flight safety and poses a threat of a disaster.

In addition, forcing the pilot to perform additional activities during the flight and in a very stressful situation (turning off the engine during the flight) is not acceptable and needs to take concrete prevention activities or redesign the start-up system.

It is also important to keep the current verification of state of control of aircraft drive unit start-up processes, which allows to avoid unnecessary loads (e.g. thermal ones) of the engine drive units. The method of phase mapping of the rotational speed growth is a very good way of such monitoring of engine control state. It pretty accurately indicates the points of excessive loads of aircraft drive units' elements.

\section{References}

[1] Dzierżanowski P., Kordziński W., Łyżwiński M., Otyś J., Szczeciński A., Wiatrek R.: Turbinowe silniki odrzutowe [Turbine jet engines]. WKL, Warszawa 1983.

[2] Kowalski M., Kozakiewicz A.: Unstable operation of the turbine aircraft engine. Journal of Theoretical and Applied Mechanics, Vol. 51, No. 3, pp. 719-727, 2013.

[3] Kowalski M., Szczepanik R.: Analiza pracy silnika PZL-10WM z pełnozakresowym, mikroprocesorowym układem typu „FADEC”, a odwzorowanie fazowe [Analysis of the operation of the PZL-10WM engine with a full authority digital engine control "FADEC" and the phase mapping]. Logistyka nr 6/2010 [Logistics no 6/2010].

[4] Kowalski M.: Phase mapping in diagnosing of the two - rotor turbojet engine. Journal of Theoretical and Applied Mechanics, vol 50, no. 4, 2012.

[5] Kowalski M.: Use of data from on-board date recorders for acceptance tests of avionic driving units. Journal of KONES Powertrain and Transport. Vol. 20, No. 2, Warsaw 2013.

[6] Kowalski M.: Zagadnienia diagnozowania turbinowych silników lotniczych $\mathrm{z}$ wykorzystaniem danych $\mathrm{z}$ pokładowych rejestratorów lotu. [Issues of aircraft turbine jet engines using data of the on-board flight recorders]. Zeszyt naukowy ITWL [AFIT Research Works] No. 31, Warsaw 2013.

[7] Piwek K., Wiśniowski W.: Small air transport aircraft entry requirements evoked by Flight Plan 2050, Aircraft, Engineering and Aerospace Technology: An International Journal 88/2 (2016) 341-347. 


\section{EFEKTYWNOŚĆ PROCESÓW ROZRUCHU TURBINOWYCH SILNIKÓW ODRZUTOWYCH}

\section{Wprowadzenie}

Proces rozruchu zespołów napędowych podczas lotu szkolnych statków powietrznych, będących na wyposażeniu Dęblińskiej Szkoły „Orląt” i przeznaczonych do szkolenia lotniczego przyszłych pilotów jest bardzo ważnym elementem z punktu widzenia bezpieczeństwa lotu.

Podczas użytkowania silnika w powietrzu istnieje możliwość jego samoczynnego wyłączenia. Przyczyn wyłączenia przy założeniu, że instalacja paliwowa działa poprawnie, jest wiele, jak np.: wykonanie gwałtownych manewrów przy wcześniejszym zmniejszeniu prędkości obrotowej silnika. Może to być spowodowane niesymetrycznym opływem wlotu silnikowego, złą regulacja dyfuzorów wlotowych, zaburzeniami przepływu spowodowane np. odpalaniem rakiet, oblodzeniem wlotu itp.

Konstrukcja układu rozruchu silnika lotniczego bardzo często jest wyznacznikiem zakresów możliwych zastosowań samolotu. System rozruchu - niezależnie od typu - składa się z trzech głównych układów: automatyki rozruchu (sprawującego także funkcję kontrolną), rozrusznika zasadniczego oraz źródła zasilania (0). Źródło zasilania może być integralną częścią statku powietrznego lub silnika (tzw. prądnico-rozrusznik).

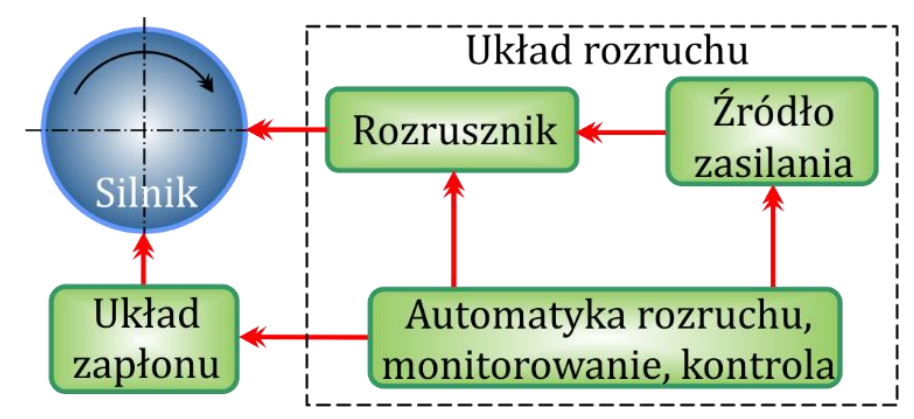

Rys. 1. Schemat uktadu rozruchu [3]

We współczesnych turbinowych silnikach odrzutowych rozruch odbywa się automatycznie, zgodnie ze specjalnie dopasowanym programem włączania i wyłączania zasilania rozrusznika, zapłonu i paliwa rozruchowego. Typ układu rozruchowego decyduje także o jego ciężarze i gabarytach, co ma istotne znaczenie, szczególnie w odniesieniu do małych samolotów, a także koniecznych działań do wykonania przez pilota podczas jego uruchamiania. 
Start-up processes' efficiency of turbine jet engines

Efektywność procesów rozruchu turbinowych silników odrzutowych

Szczególnie jest to istotne podczas szkolenia lotniczego w powietrzu przyszłych pilotów i jest bezpośrednio związane z bezpieczeństwem wykonywania lotów [7].

Zadaniem układu rozruchu silnika lotniczego jest nadanie niezbędnej prędkości obrotowej pędni silnika (zespół sprężarki i turbiny), przy której moc rozwijana przez turbinę $N_{t}$ jest większa od sumy mocy pobieranej przez sprężarkę $N_{s}$ i inne podzespoły silnika - zgodnie z bilansem mocy turbiny określonej zależnością:

$$
N_{t} \geq N_{S}+N_{a g r}
$$

gdzie: $\boldsymbol{N}_{\boldsymbol{a g r}}-$ moc potrzebna do napędu agregatów i pokonania oporów tarcia.

Rozruch silnika jest procesem nieustalonym trwającym od stanu spoczynku do osiągnięcia niezbędnej, minimalnej prędkości obrotowej w warunkach naziemnych, a podczas lotu również od minimalnej prędkości „autorotacji” do minimalnej prędkości obrotowej (często nazywanej minimalną prędkością lotną). Rozruch silnika w zakresie do minimalnej prędkości obrotowej musi odbywać się w nieprzerwany sposób, z określonym przyspieszeniem.

Badania i analizę procesów rozruchu przeprowadzono m.in. na silniku PT6A-25C firmy Pratt \& Whitney stanowiącym napęd samolotu PZL-130TC-II „Olik”, na silniku PZL-10WM stanowiącym napęd śmigłowca W-3 „Sokół” oraz silniku turboodrzutowym SO-3 z samolotu TS-11 „Iskra”. Są to podstawowe statki powietrzne na wyposażeniu Dęblińskiej Szkoły Orląt, których zadaniem jest zabezpieczenie praktycznego szkolenia lotniczego w powietrzu [1, 2]. Dane do analizy zostały pozyskane $\mathrm{z}$ pokładowych rejestratorów parametrów lotu typu S2-3a produkcji Instytutu Technicznego Wojsk Lotniczych, które są zabudowane w ww. statkach powietrznych. Analizę prowadzono głównie z wykorzystaniem tzw. portretów fazowych wybranych parametrów pracy silnika, opisywane ogólną zależnością:

$$
\frac{d X}{d t}=f(X)
$$

gdzie: $X$ - analizowany parametr,

$$
t-\operatorname{czas}[\mathrm{s}] \text {. }
$$

Ponadto, zwrócono uwagę, że wartość przyspieszenia silnika ma decydujący wpływ na uzyskiwany czas rozruchu, który jest jednym z głównych parametrów wszystkich układów rozruchu. Wskazano, że aby przyspieszenie było na wymaganym poziomie, koniecznym jest zabezpieczenie tzw. nadwyżki mocy, która wymaga nieprzerwanego dopływu paliwa i powietrza do komory spalania silnika. Przedstawiono wybrane charakterystyki uzyskane podczas analizy procesów rozruchu poszczególnych zespołów napędowych podczas lotu. 


\section{Procedury rozruchów silników lotniczych}

Rozruch silnika turbośmigłowego jest nieco innych niż silnika odrzutowego. Wynika to z tego, że określona prędkość obrotowa turbiny sprężarki jest wywołana głównie autorotacją śmigła nastawionego na odpowiednie kąty natarcia. W zależności od kąta ustawienia łopat śmigła istnieje kilka możliwości współpracy śmigła z silnikiem. Najkorzystniejszym jest, gdy łopaty ustawione są w tzw. „chorągiewkę" (kąt natarcia śmigła w odniesieniu do płaszczyzny obrotu bliski $90^{\circ}$ ), co daje minimum oporu aerodynamicznego. Nadwyżkę mocy turbiny od ciśnienia dynamicznego jest zużywana na wewnętrzne dławienie strumienia powietrza w silniku.

Dla zespołu napędowego samolotu szkolnego typu PZL-130TC-II „Orlik”, (silnik PT-6A) brak jest automatycznej możliwość przechodzenia śmigła w położenie „chorągiewki”. Pilot zobowiązany jest do ręcznego przestawienia dźwigni mocy (rys. 2) na zakres prędkości obrotowej biegu jałowego, aby zaatakować mikrowyłącznik odpowiedzialny za przestawienie łopat śmigła w „chorągiewkę”. Rozwiązanie takie nie jest zbyt szczęśliwe $\mathrm{z}$ punktu widzenia konieczności właściwego reagowania załogi w sytuacji mocno stresowej, jaka często ma miejsce podczas samoczynnego wyłączenia silnika, szczególnie w odniesieniu do początkujących pilotów.

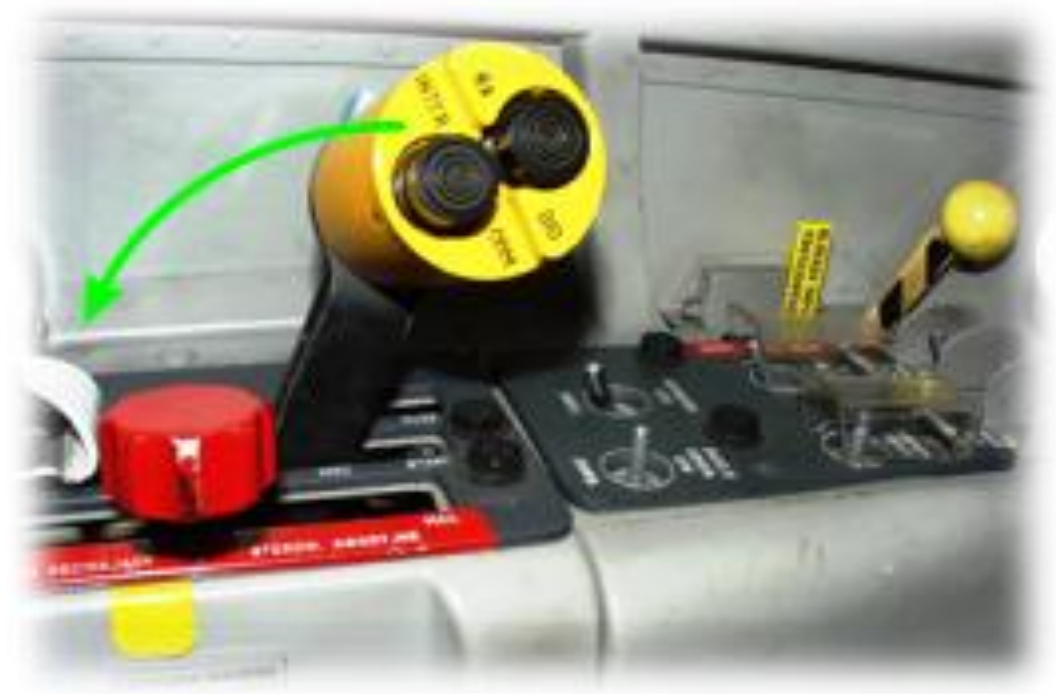

\section{Rys. 2. Widok dźwigni mocy (strzałka zielona - kierunek przestawienia dźwigni)}

W trakcie badań kwalifikacyjnych przeprowadzono trzy kolejne rozruchy w powietrzu, na wysokości około $3000 \mathrm{~m}$ i prędkości lotu w zakresie od 230 do $260 \mathrm{~km} / \mathrm{h}$. Pierwszy wykonano po 30 sekundach od momentu wyłączenia silnika, drugi w momencie, gdy prędkość obrotowa silnika zmniejszy się poniżej $50 \%$ i trzeci - również po 30 sekundach od wyłączenia w sposób awaryjny $[4,5]$. 
Start-up processes' efficiency of turbine jet engines

Efektywność procesów rozruchu turbinowych silników odrzutowych

\section{Wyniki rozruchów silników lotniczych podczas lotu}

Zobrazowanie poszczególnych uruchomień tego silnika przedstawiono na rys. 3, gdzie zaprezentowano przebieg prędkości obrotowej silnika w funkcji czasu trwania lotu.

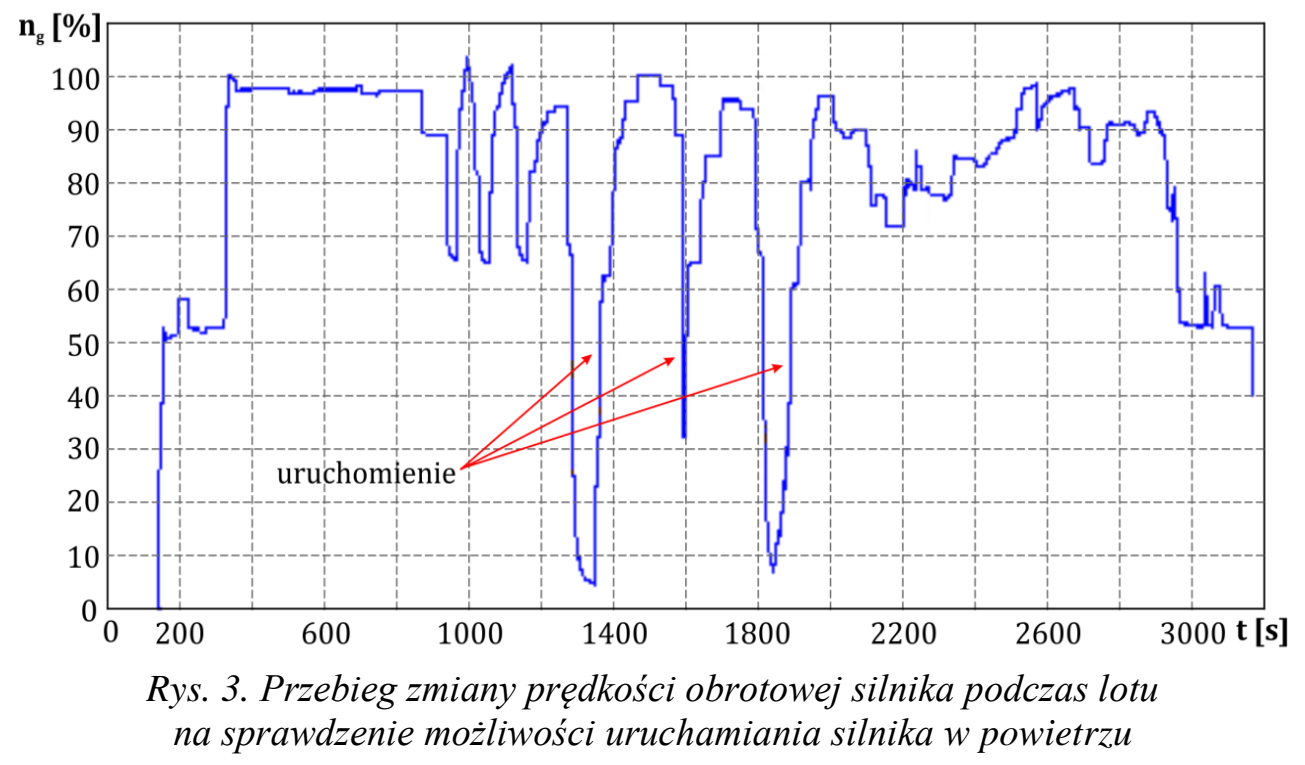

Podczas rozruchu silnika w powietrzu śmigło - w pewnym zakresie kątów natarcia - jest dodatkowym źródłem znacznego momentu obrotowego, wielokrotnie przewyższającego maksymalny moment obrotowy rozrusznika. Stąd czas potrzebny do osiągnięcia prędkości obrotowej biegu jałowego (małego gazu) przez silnik jest nieznacznie krótszy od czasu rozruchów na ziemi. Przebiegi czasowe zmiany prędkości obrotowej silnika podczas wykonywania analizowanych uruchomień pokazują nieznaczne ich skrócenie, poza uruchomieniem awaryjnym.

Prowadzona analiza zmiany podstawowych parametrów pracy zespołu napędowego podczas kolejnych rozruchów pozwala na określenie, który sposób rozruchu jest najefektywniejszy i najłagodniej przebiega.

Kolejnym przykładem wskazującym na utrudnienia w procesie uruchomienia lotniczego zespołu napędowego jest zastosowana procedura rozruchu silnika typu PZL-10WM, zabudowanego w polskim śmigłowcu W-3A „Sokół”. Silnik typu PZL-10WM, wyposażony jest w mikroprocesorowy układ paliwowo-regulacyjny typu FADEC.

W ramach prób w locie wykonano tzw. rozruchy zimne oraz gorące na wysokościach do $4000 \mathrm{~m}$. W jednym przypadku na wysokościach powyżej $3000 \mathrm{~m}$ (tj. 3500 i $4000 \mathrm{~m}$ ) próby wykonania rozruchów nie udały się. Powodem tego stanu rzeczy było nie włączenie dodatkowego upustu powietrza (np. na potrzeby płatowca - nakazane w Instrukcji Użytkowania tego silnika). 
Na rys. 4 przedstawiono jedną z prób nieudanego rozruchu silnika lewego w locie na wysokości $H \approx 3500 \mathrm{~m}$, dla prędkości lotu $V_{p} \approx 115 \mathrm{~km} / \mathrm{h}$. Widoczne odwzorowanie fazowe jest typowe dla pracy samego rozrusznika, co sugeruje, że wzrost prędkości obrotowej $n_{1}$ do blisko $30 \%$ było tylko następstwem pracy rozrusznika [6].

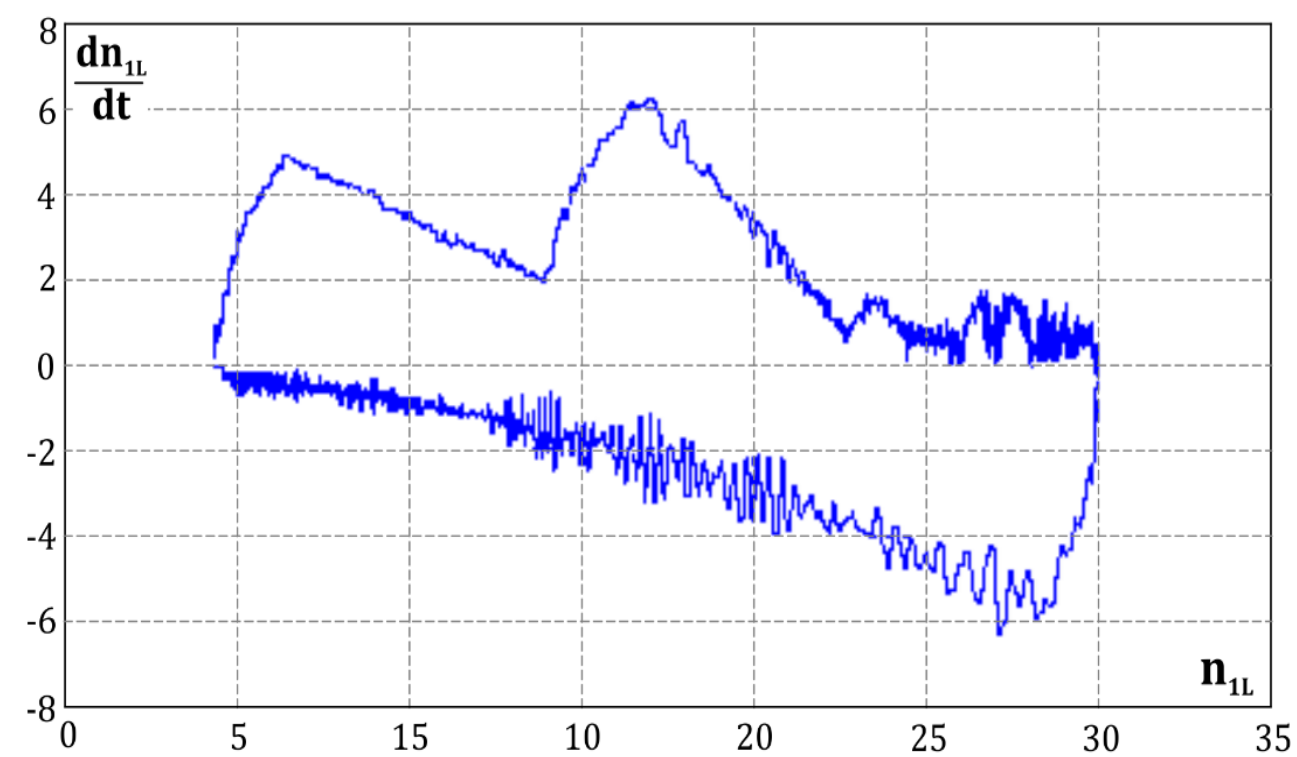

Rys. 4. Odwzorowanie fazowe przyrostu prędkości obrotowej silnika $n_{1 L}$ podczas nieudanego rozruchu $w$ locie

Patrząc na przebieg prezentowany na rys. 5 obrazujący natężenie przepływu paliwa podawanego do komory spalania w funkcji prędkości obrotowej turbosprężarki $n_{l}$, można stwierdzić, że przy odpowiednim ciśnieniu powietrza $\mathrm{p}_{2}$ za sprężarką silnika rozruch zakończyłby się wynikiem pozytywnym.

W kolejnych sprawdzeniach, po uwzględnieniu konieczności dodatkowego upustu powietrza ze sprężarki, próby były już pozytywne, a ich parametry były zgodne z warunkami technicznymi (WT). Należy jednak zaznaczyć, że zaistniały przypadek nie uruchomienia się silnika na dużych wysokościach, przy występowaniu ujemnych temperatur otoczenia, bez zastosowania dodatkowego upustu powietrza jest dużym problemem, wartym głębszej analizy. Wymaga bowiem pamiętania przez załogę o dodatkowych czynnościach w sytuacji mocno stresowej (sytuacja awaryjna) oraz przy bardzo często występującym deficycie czasu. $\mathrm{Z}$ tego powodu skierowano do Producenta śmigłowca wniosek o rozpatrzenie możliwości programowego uwzględniania tego rodzaju sytuacji bezpośrednio $\mathrm{w}$ bloku elektronicznym, oczywiście $\mathrm{w}$ fazie dalszego rozwoju i modernizacji mikroprocesorowego układu paliwowo-regulacyjnego. 
Start-up processes' efficiency of turbine jet engines

Efektywność procesów rozruchu turbinowych silników odrzutowych

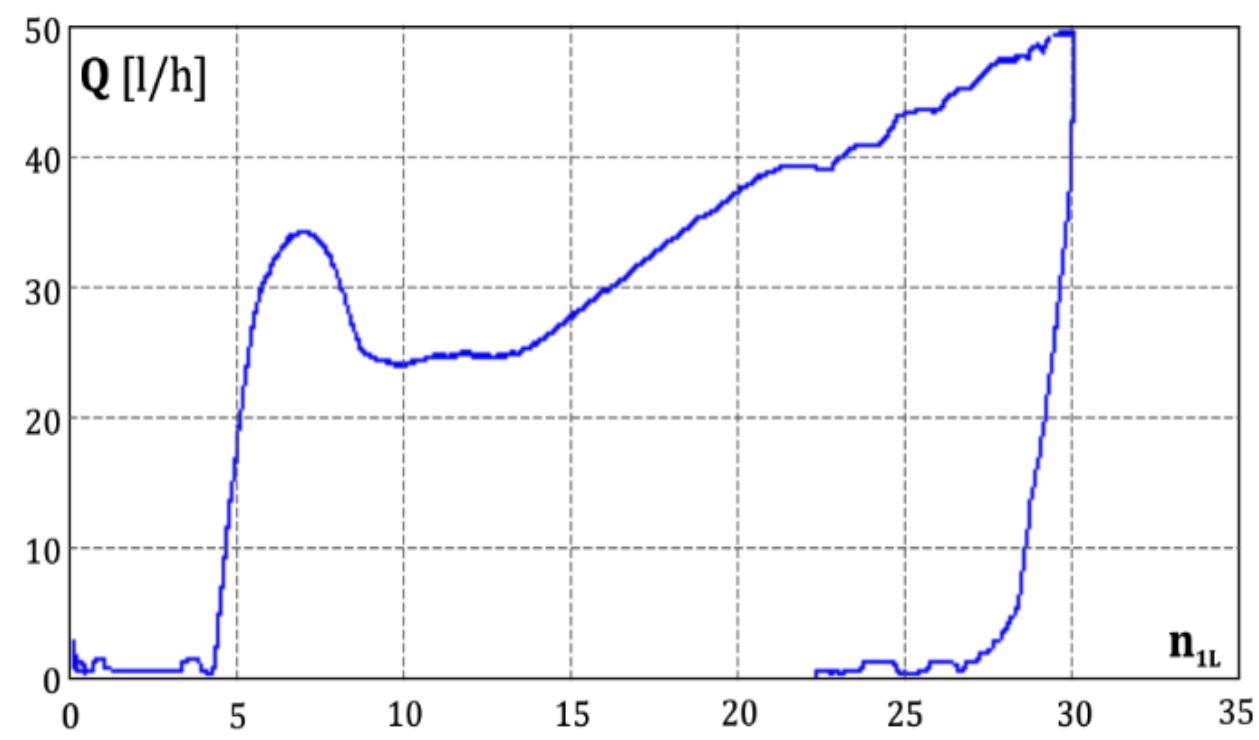

Rys. 5. Natężenie przeptywu paliwa $Q$ w funkcji prędkości obrotowej turbosprężarki N1 podczas nieudanej próby rozruchu silnika lewego w locie

Następny przykład bardzo złożonej procedury uruchomienia (podczas lotu) dotyczy jednoprzepływowego, turbinowego silnika odrzutowego typu SO-3 zabudowanego w samolocie TS-11 „Iskra”. Samolot ten jest dość prostym w obsłudze - przeznaczonym do szkolenia zaawansowanego młodych pilotów w Wyższej Szkole oficerskiej Sił Powietrznych w Dęblinie - Polska. W nakazanej procedurze uruchomienia silnika podczas lotu jest wiele czynności do zrealizowania, które w dodatku należy wykonywać w odpowiedniej kolejności. Ponadto, występuje konieczność ciągłej obserwacji przyrostu temperatury gazów wylotowych, aby nie przekroczyć maksymalnie dopuszczalnej wartości, tj. $800^{\circ} \mathrm{C}$. Jest to bardzo ważne, gdyż jej przekroczenie zmusza pilota do przerwania rozruchu silnika. Ponowna próba uruchomienia silnika, po takim przerwaniu wymaga tzw. przedmuchania silnika w ciągu 20 sekund w celu pozbycia się nadmiernej ilości paliwa, która - w skrajnych przypadkach - może doprowadzić do pożaru. Jest to bardzo niebezpieczne $\mathrm{z}$ uwagi na dość częsty brak czasu na realizacje tych wszystkich czynności i wymaga wdrażania zautomatyzowanych układów rozruchowych.

Należy jednak pamiętać, że bardzo często, po nieudanych próbach uruchomienia silnika, niezbędnym jest przeprowadzenie analizy przyczyn tego zdarzenia. Pozwoli to na opracowanie odpowiedniej profilaktyki i uniknięcie tego rodzaju zdarzeń w następnych lotach szkolnych. Do przeprowadzenia tego typu analiz można zastosować m.in. wspomnianą już metodę odwzorowania fazowego przyrostu prędkości obrotowej. Pozwala ona m.in. na rozpoznawanie nieprawidłowości w regulacji silników poprzez kompleksową analizę pracy (lub stanu technicznego) wszystkich elementów układu rozruchowego silnika. 
Przyrost prędkości obrotowej silnika podczas rozruchu w funkcji czasu daje (niekiedy) dość słabo zauważalne symptomy jej zachwiania (linia okręgu na rys. 6).

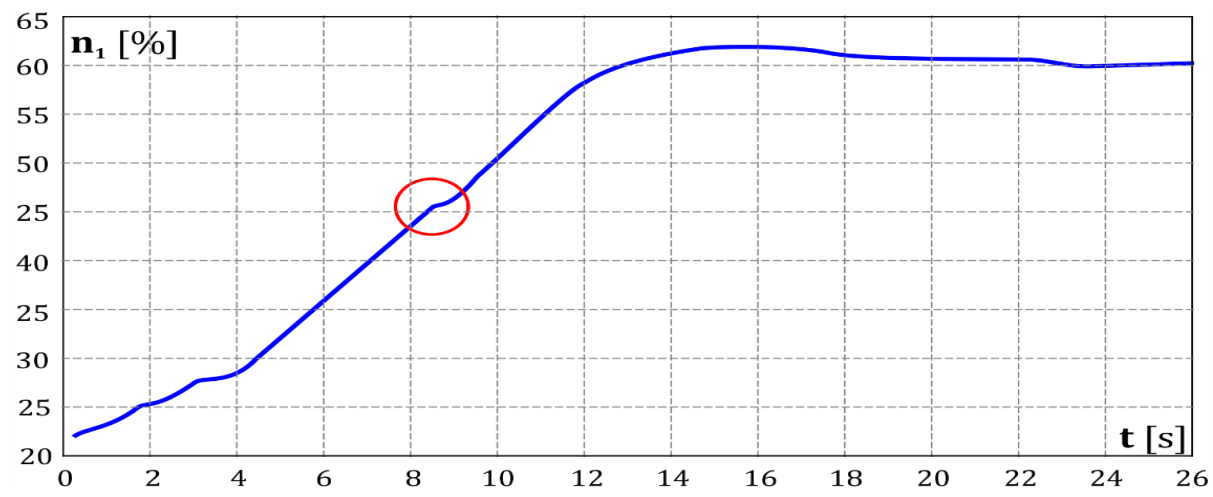

Rys. 6. Zmiana prędkości obrotowej silnika w czasie rozruchu silnika typu SO-3 podczas lotu

Prezentując dopiero tzw. portret fazowy przyrostu prędkości obrotowej, można dość jednoznacznie zaobserwować, że to niewielkie zachwianie przyrostu prędkości obrotowej jest wynikiem np. zadziałania ogranicznika przyrostu temperatury gazów wylotowych, który wyhamowuje jej wzrost przez dość gwałtowne zmniejszenie ilości paliwa podawanego do komory spalania. Takie zjawisko jest zilustrowane na rys. 7, gdzie, w wyniku dość gwałtownego gradientu przyrostu prędkości obrotowej (wskutek podawania nadmiernej ilości paliwa do komory spalania), przy względnej prędkości obrotowej około $45 \%$, nastąiło istotne zmniejszenie ilości podawanego paliwa, co spowodowało zmniejszenie prędkości obrotowej, a tym samym nastąpił spadek gradientu temperatury gazów wylotowych.

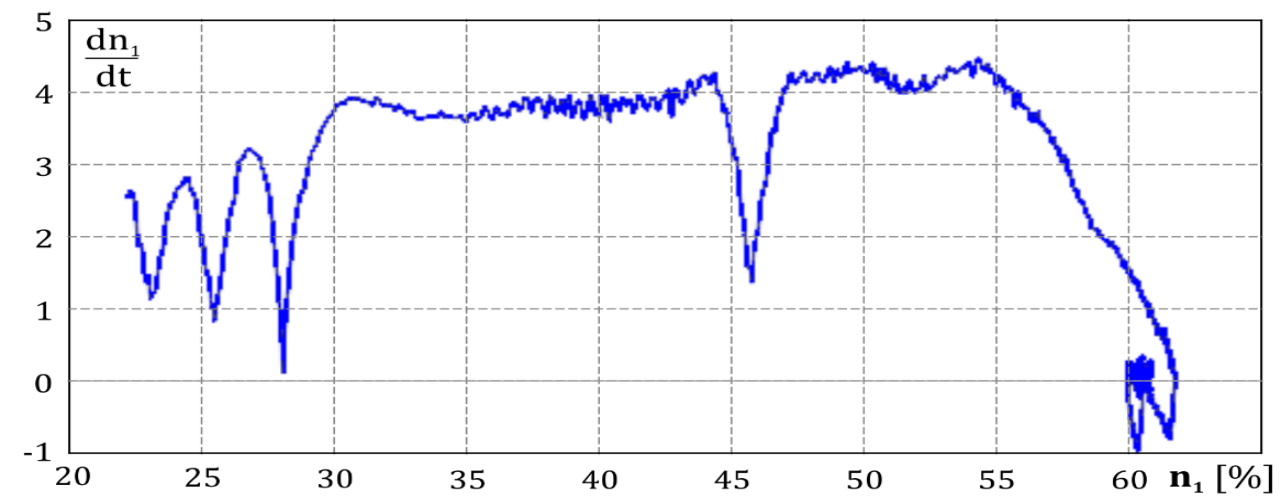

Rys. 7. Odwzorowanie fazowe przyrostu prędkości obrotowej podczas rozruchu 4. silnika w locie 
Start-up processes' efficiency of turbine jet engines Efektywność procesów rozruchu turbinowych silników odrzutowych

Taki stan rzeczy mocno nadwyręża - szczególnie wirujące elementy silnika (jak np. łopatki sprężarki i turbiny) - wskutek występujących przy tym nadmiernych obciążeń termicznych.

Tego rodzaju analiza pozwala na wcześniejszą reakcję i doregulowanie układu rozruchowego silnika, co istotnie może zmniejszyć niekorzystne zjawiska przyspieszające procesy destrukcji wrażliwych elementów silnika lotniczego.

Na rys. 8 i 9 przedstawiono podobne charakterystyki, ale już po przeprowadzonej regulacji silnika, która wyraźnie zmniejszyła dynamikę przyrostu prędkości obrotowej silnika $n_{1}$ podczas rozruchu, a tym samym uległ zmniejszeniu gradient temperatury gazów wylotowych, co powodowało nadmierne obciążenie elementów silnika, szczególnie elementów wirujących. Wynika to głównie z tego, że na mocno schłodzone łopatki, działają gazy wylotowe o bardzo wysokiej temperaturze. To istotnie osłabia wytrzymałość zmęczeniową tych elementów i może doprowadzić do ich urwania (uszkodzenia).

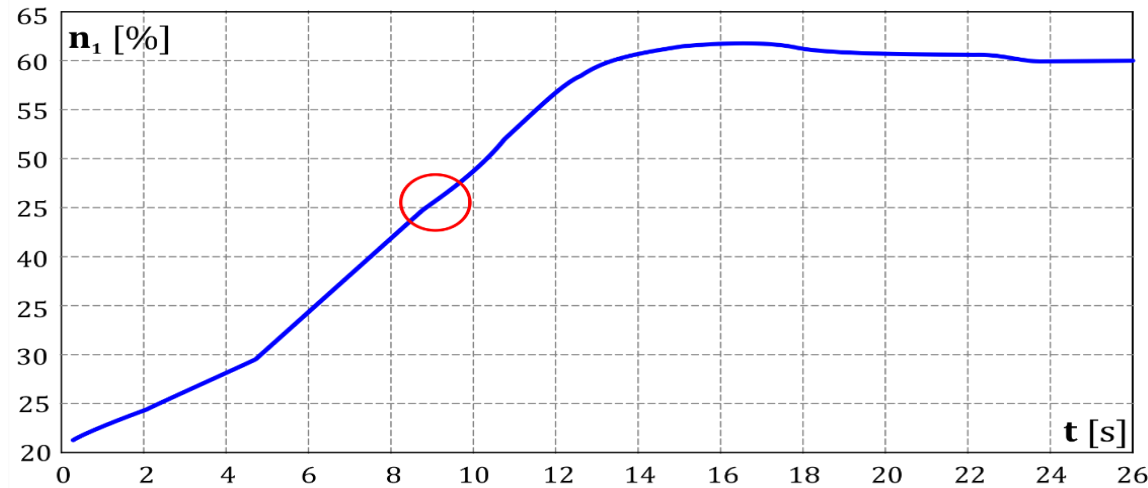

Rys. 8. Zmiana prędkości obrotowej silnika w czasie rozruchu silnika typu SO-3 podczas lotu (widoczne dużo mniejsze załamanie przyrostu prędkości obrotowej)

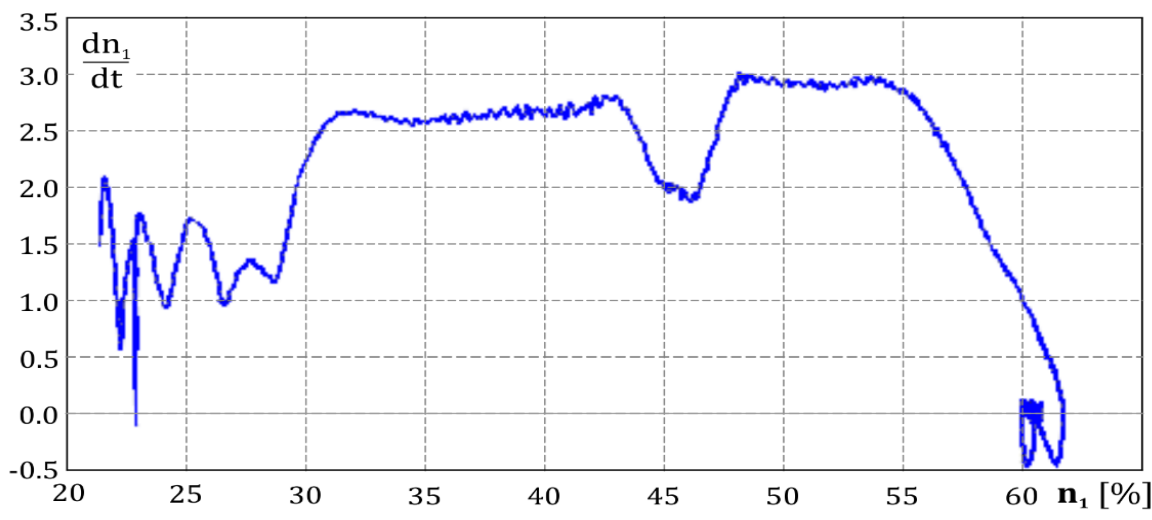

Rys. 9. Odwzorowanie fazowe przyrostu prędkości obrotowej podczas rozruchu silnika w locie (widoczne dużo mniejsze wyhamowanie prędkości obrotowej) 


\section{Podsumowanie}

Prowadzone analizy procesów rozruchu zespołów napędowych wykazują, że układy rozruchu zespołów napędowych są efektywne i zapewniają prawidłową pracę (praktycznie) w każdych warunkach. Nie są jednak pozbawione drobnych wad, których istnienie ma bezpośredni wpływ na bezpieczeństwo lotów i wymaga podejmowania działań profilaktycznych lub nawet modernizacji niektórych elementów danego układu rozruchowego.

Szczególnie zwrócono uwagę na przypadki nie uruchomienia się silników podczas lotu, na które miały wpływ głównie narzucone pilotowi czynności dodatkowe, bez których jest niemożliwym wręcz uruchomienie silnika podczas lotu. Ma to bardzo istotne znaczenie z punktu widzenia bezpieczeństwa lotu i grozi katastrofą.

Ponadto zmuszanie pilota do wykonywania dodatkowych czynności podczas lotu i to w sytuacji mocno stresowej (wyłączenie silnika podczas lotu) jest nie do przyjęcia i wymaga podjęcia konkretnych działań profilaktycznych lub zmian konstrukcyjnych układu rozruchowego silnika.

Ważnym jest również prowadzenie bieżącej weryfikacji stanu regulacji procesów uruchomienia lotniczych zespołów napędowych, co pozwala na unikanie niepotrzebnych obciążeń (np. termicznych) układów napędowych silnika. Bardzo dobrym sposobem na takie monitorowanie stanu regulacji silników jest metoda odwzorowania fazowego przyrostu prędkości obrotowej, która dość precyzyjnie wskazuje na miejsca nadmiernych obciążeń elementów lotniczych zespołów napędowych.

\section{Literatura}

[1] Dzierżanowski P., Kordziński W., Łyżwiński M., Otyś J., Szczeciński A., Wiatrek R.: Turbinowe silniki odrzutowe. WKŁ, Warszawa 1983.

[2] Kowalski M., Kozakiewicz A.: Unstable operation of the turbine aircraft engine. Journal of Theoretical and Applied Mechanics, Vol. 51, No. 3, pp. 719-727, 2013.

[3] Kowalski M., Szczepanik R.: Analiza pracy silnika PZL-10WM z pełnozakresowym, mikroprocesorowym układem typu „FADEC”, a odwzorowanie fazowe. Logistyka nr 6/2010.

[4] Kowalski M.: Phase mapping In diagnosing of the two - rotor turbojet engine. Journal of Theoretical and Applied Mechanics, vol 50, no. 4, 2012.

[5] Kowalski M.: Use of data from on-board date recorders for acceptance tests of avionic driving units. Journal of KONES Powertrain and Transport. Vol. 20, No. 2, Warsaw 2013. 
Start-up processes' efficiency of turbine jet engines Efektywność procesów rozruchu turbinowych silników odrzutowych

[6] Kowalski M.: Zagadnienia diagnozowania turbinowych silników lotniczych z wykorzystaniem danych z pokładowych rejestratorów lotu. Zeszyt naukowy ITWL nr 31, Warszawa 2013.

[7] Piwek K., Wiśniowski W.: Small air transport aircraft entry requirements evoked by Flight Plan 2050, Aircraft, Engineering and Aerospace Technology: An International Journal 88/2 (2016) 341-347.

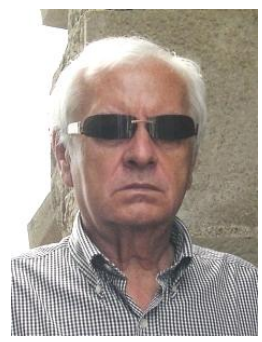

Prof. dr hab. inz. Antoni Jankowski jest absolwentem Wydziatu MEL Politechniki Warszawskiej, gdzie uzyskat stopień magistra inż. $\quad w$ specjalności silniki lotnicze oraz doktora nauk technicznych. Obecnie pracuje w Instytucie Lotnictwa i Instytucie Technicznym Wojsk Lotniczych, gdzie uzyskat stopień dr. hab. W roku 2013 uzyskat tytut naukowy prof. nauk technicznych. Obszar jego zainteresowań naukowych, to: budowa i eksploatacja maszyn, w tym silniki spalinowe, procesy spalania i ekologia środków transportu, inżynieria materiałowa. W dorobku ma ok. 200 publikacji naukowych, $w$ tym 17 patentów, w tym 1 patent na silnik Meteor 2 do rakiety, która przekroczyta granice kosmosu, oraz ma około 200 opracowań naukowo-technicznych $w$ większości wdrożonych do praktyki. Byt i jest polskim delegatem do światowych organizacji naukowych CIMAK i FISITA, organizatorem licznych konferencji i kongresów naukowych. Jest recenzentem i promotorem prac doktorskich i habilitacyjnych (Udziat 50\%).

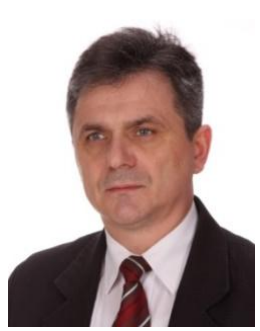

Dr hab. inz. Mirostaw Kowalski, prof. ITWL jest absolwentem Wojskowej Akademii Technicznej w Warszawie, która ukończyt w 1987 roku. Pracuje w Instytucie Technicznym Wojsk Lotniczych w Warszawie na stanowisku Zastępcy Dyrektora ITWL ds. Organizacyjno-Technicznych oraz w Wyzszej Szkole Oficerskiej Sit Powietrznych w Dęblinie na stanowisku profesora nadzwyczajnego. Gtówne obszary dziatalności to teoria, konstrukcje i diagnostyka lotniczych zespołów napędowych (udziat 50\%). 